An environmental approach to police misconduct: exploring situational prevention possibilities to understanding and preventing police misconduct

\begin{tabular}{|r|l|}
\hline Journal: & Policing: An International Journal \\
\hline Manuscript ID & PIJPSM-07-2020-0119.R1 \\
\hline Manuscript Type: & Research Paper \\
\hline Keywords: & Police, Law Enforcement, Misconduct, Crime Prevention \\
\hline \multicolumn{2}{l}{} \\
\end{tabular}




\title{
An environmental approach to police misconduct: Exploring situational prevention possibilities
}

\section{to understanding and preventing police misconduct}

\begin{abstract}
Purpose

This paper explores the applicability of environmental theories to understanding patterns of police misconduct. In turn, it aims to offer a method for identifying prevention techniques that can be practically applied by policing agencies.
\end{abstract}

\section{Method}

The study empirically examined 84 substantiated matters of police misconduct in Queensland, Australia. The matters were content analysed for elements of the first level of the crime triangle. These elements were then analysed to identify their relationships with the situational precipitators that initiated the misconduct; proactive misconduct and situational misconduct.

\section{Findings}

The two types of initiating misconduct had differing relationships with the crime triangle elements. Therefore, specific prevention techniques can be tailored by policing agencies to address and prevent each type of misconduct more successfully. The paper discusses these findings in terms of preventative measures according to the second preventative level of the crime triangle and situational crime prevention techniques.

\section{Originality}

This paper provides an alternative approach to understanding and preventing police misconduct by exploring the applicability of environmental theories. It finds that environmental theories offer a feasible approach for policing agencies to understand and tailor prevention of police misconduct in their jurisdictions. 
Members of the public entrust the police for safety and security, with the public largely dependent on police to uphold the law. In order for the police to do this, we allow them to conduct their duties with discretion and substantial powers. However, this role and associated functions provide opportunities for behaviour that deviates from their charter. The UK Home Office (2019) recently reported 2,809 matters of misconduct or gross misconduct across England and Wales during the last reporting year, while the US Department of Justice estimate that non-federal officers are arrested at a rate of 0.72 per 1,000 officers for police crime (Stinson, et al., 2016). Son and Rome (2005) suggest that officers are typically engaging with only minor types of misconduct (such as accepting free coffee/food and sleeping while on duty). However, they also found more serious types of misconduct occurring (such as racial harassment and excessive force). The consequences of police misconduct can be dire, resulting in physical harm and financial burdens (Office of Police Integrity, 2012). Loss of trust in police by the public can result in a lack of cooperation between the public and police which can spiral into disrespect for the law and retaliation (Tyler, 2017). Hence, police misconduct remains one of the most critical issues in policing today.

Strategies used to address the issues of police misconduct tend to be reactive approaches that are time consuming, complex, and difficult to implement (Punch, 2000) and contemporary risk assessment tools are suboptimal (Worden, Harris, \& McLean, 2014). Therefore, an alternative approach that is practical, proactive, and targeted is needed to understand and prevent police misconduct from occurring. One such approach is environmental theories, such as Situational Crime Prevention (SCP). SCP techniques have been successful in the prevention of a range of different crime problems. Examples include, prisoner control (Wortley, et al., 2002), street crime (Sloan-Howitt, \& Kelling 1990), violence (Hauritz, et al., 1998), aircraft hijacking (Wilkinson 1986), robbery (Ekblom 1988), and obscene phone calls (Clarke 1990). The present study examines the applicability of environmental theories to describe police misconduct and suggest possible prevention techniques. To do this, the paper examines the application of the Crime Triangle (Eck, 1994) to examine real-world substantiated cases of police misconduct. Doing so then allows targeted discussion of possible SCP techniques. Thus, this paper uses analysis of specific features of police misconduct cases to propose that SCP techniques may be usefully applied and, consequently, offer a practical and targeted approach to police misconduct that can be implemented by policing agencies and authorities. 


\section{The Current Proposed Approach: Environmental Theories of Crime Prevention}

Environmental theories focus on the situation of a crime rather than the complexities of psychological and social characteristics of criminality. They aim to manipulate the immediate environment in order to prevent crime from occurring (Clarke 2010). Rational choice theory (RCT) subscribes to the notion that criminal behaviour is both rational and purposive (Clarke 2010), where individuals weigh up the costs and benefits of a decision, thus making a rational choice to commit a criminal act. RCT also suggests that crime is specific; that is, there is a differentiation between crimes. In the case of police misconduct, this implies that different forms of police 'deviant' behaviour involve different circumstances and motivations and, therefore, require different approaches to prevention.

Indeed, Wortley (2011) argues that the situational precipitators of crime need to be considered in conjunction with the immediate environment of the rational choice perspective. While the immediate environment can enable the offender (according to rational choice perspective), the situational precipitators can initiate the deviant behaviour (Wortley, 2011). Furthermore, Wortley (2011) suggests that the situational precipitator perspective takes a different approach to examining the motivation of the offender - that of being situationally dependent (i.e. a deviant act by an officer as a response to the situation) compared with being already motivated (i.e. a deviant act by an officer who proactively seeks out opportunities); in turn, requiring different prevention strategies. Therefore, it is important to consider the different initiations for police misconduct in order to identify preventative strategies.

Extending from the theories outlined above, routine activity theory suggests that, for a crime to occur, three elements converge in time and space (Cohen \& Felson 1979). Eck's (1994) crime triangle consists of an offender, place, and target and was later expanded to include a second preventative level of handlers, managers, and guardians respectively (Eck 1994; Sampson, et al., 2010). Carmel-Gilfilen (2013) adapted the original crime triangle to include motivations stating that "in order for a crime to occur there must be a suitable target with opportunity available, the ability to acquire this product in a specific place and desire on the part of the offender to complete the crime" (p. 83). Figure 1 illustrates a combination of these approaches. 
Situational crime prevention (SCP) draws from the above environmental theories to offer a practical and proactive approach that focuses on prevention of crime, rather than a reactive approach that seeks to identify and discipline offenders. It does this by examining the crime and the situation in which it occurred; it aims to control the crime, avoiding the complexities involved in controlling the offender. The latest classification of SCP contains 25 techniques that are grouped into five approaches (see Table 1): 'Increase the Effort', 'Increase the Risk', 'Reduce the Rewards', 'Reduce Provocations', and 'Remove Excuses' (Cornish \& Clarke 2003, p. 90). Overall, SCP offers a proactive approach that does not preclude the implementation of other strategies. Furthermore, by blocking the opportunities for crime to occur, deviant subcultures may fail to cultivate (Cornish \& Clarke, 2003).

We propose that applying the crime triangle to police misconduct will enable understanding of the situational elements of the officer, place and targets involved in misconduct. These elements offer possible areas for prevention. Further, understanding patterns of how these elements converge with situational precipitators in cases of misconduct increases understanding of 'types' of cases. This can, in turn, inform police departments of how to focus prevention strategies.

\section{***INSERT TABLE 1 HERE***}

\section{Typologies of Police Misconduct}

Traditional typologies tend to be narrow in their criteria and, therefore, omit key types of behaviour, particularly new and emerging forms of police misconduct. For example, Roebuck and Barker (1974) created a detailed typology of eight distinct types of behaviour, which was later expanded to include a ninth category by Punch (1985). For example, they made the distinction between 'Corruption of Authority' as receiving money or gifts because of their role as a police officer, and 'Kickbacks' as the acceptance of money or gifts for referring business (p. 428-429). However, the typology focuses only on the individual officer and is not inclusive of group or organisational level corruption. Overall, these early classifications are helpful at the descriptive level, but often omit some forms of misconduct and do not allow for new and emerging forms of police misconduct. 
Broader definitions of misconduct have also been proposed, by outlining the confinements of the topic's boundaries. Wilson (1968) suggested a clear distinction between activities that should be included (such as accepting bribes), and activities that should not be included (such as 'criminal' activities, for example burglary while on duty). However, Stinson and colleagues (2016) highlight the importance of including criminal activities (or police crime) as types of police misconduct, for they too can damage police integrity and legitimacy. Kane and White (2009) constructed their own classification to be both inclusive of off-duty activities but also recognising their distinction from on-duty misconduct. Specifically, they focused on career-ending misconduct to find risk factors (e.g. prior criminality and busy patrol assignments) and protective factors (e.g. well-educated and career advancements) for police misconduct. Some authors such as Kleinig (1996) use a wider definition describing it as occurring when an officer's intention is for personal gain, which consequently omits other intentions such as 'noble cause'.

Punch (2000) attempted to provide a broad typology that is inclusive of individual, group, and organisational levels of police misconduct. He achieved this by grouping forms of police misconduct into three main types; corruption, misconduct, and police crime. Sub-types were then established under each of these headings. While this typology does attempt to encompass all forms of police misconduct and does appear to allow for new and emerging forms, at times the typology can be either too narrow in its definitions or too broad. For example, the category of 'corruption' details four sub-types while 'misconduct' does not include any sub-types and tends to be a catch-all approach for when officers breach any policies and rules within the police service. Consequently, finding a preventative approach that is both suitable and successful for such a broad category may be difficult.

More recently, researchers have sought to explore police misconduct on a multidimensional level. Dean et al., (2010) provide a theoretical conceptual framework, creating a two-dimensional model depicting categories as well as levels of police deviance, reflecting the 'slippery slope'. Dean et al., (2010), therefore, offer a model that is both descriptive of the nature of activities and which also incorporates elements that may suggest causes of the behaviour. While their model is theoretical rather than empirically-driven, Dean and Gottschalk (2011) used the typology to classify 60 Norwegian cases of police misconduct from a five-year period, with all but two of the subtypes represented in the data. They refined the original two-dimensional model to include nine motivations and established a scale of seriousness. While both studies are useful at identifying types of police misconduct and seriousness, the model does not provide a means to prevent the misconduct from occurring. 
Furthermore, addressing the complexities of the underlying nine motivations may be time consuming and difficult.

Porter and Warrender (2009) explored the nature of police misconduct through analysis of multiple features of misconduct cases, including who was involved, in what ways, and for what purpose. While not specifically applying environmental theories, their framework explored some of the crime triangle elements with the purpose of identifying the combinations (or convergence) of elements to aid targeted prevention of misconduct types. Based on the content analysis of 50 UK law reports, the combinations of these features produced three broad level categories. The category labelled 'Police Crime' (p. 87) described constables acting proactively by themselves committing single offences for their own personal gain. The second category, labelled 'Noble Cause Misconduct', contained officers acting with other officers in response to the situation. The last category was labelled 'Corruption' and consisted of higher ranked officers committing multiple offences involving civilians and for their own personal gain. These broad categories, or types, were identified empirically, based upon the most frequently occurring combinations of specific elements. Porter and Warrender (2009) suggested that knowledge of these types and their specific elements helps us to understand the causes of these incidents (beyond just labelling the activity), which in turn could help to tailor prevention strategies. These findings therefore support the premise of applying an environmental approach to police misconduct.

\section{The Present Study}

While existing typologies of police misconduct are useful in their description of police misconduct, they can often be complex in nature making it difficult for policing agencies to apply for preventive purposes. An environmental perspective applied to police misconduct may offer a simpler approach to not only understanding the nature of police misconduct, but also providing techniques to prevent it from occurring that can be implemented by policing agencies. The present study uses substantiated cases of serious ${ }^{1}$ police misconduct to examine the applicability of environmental theories to describe police misconduct and suggest possible prevention techniques. First, elements of the first level of the crime triangle are operationalised and explored in the data, based on Carmel-Gilfen's (2013) adaptation of

\footnotetext{
${ }^{1}$ Serious cases include matters of official misconduct that if proven, provide reasonable grounds for dismissal or involve dishonest exercise of powers, breach of trust, or misuse of information (Crime and Misconduct Commission, 2010, p. 28-36).
} 
Eck's (1994) crime triangle. Next, in line with Wortley's (2011) situational precipitators of crime, each crime triangle element is analysed to identify associations with the initiation for the police misconduct to occur, to identify patterns and trends according to the initiation (whether proactively motivated or situationally dependent). From these findings, possible preventative techniques are identified from the second preventative level of the crime triangle and the 25 situational crime prevention techniques (SCP) (Cornish \& Clarke, 2003). The paper therefore tests the applicability of a framework that police departments could apply to cases of misconduct for the purpose of understanding patterns and designing tailored prevention.

\section{Methods}

\section{Setting of the Current Research}

The study's sample is taken from Queensland, Australia. Queensland is one of the three largest policing agencies in Australia in terms of number of officers, the size of the population they police, and the size of the geographical location (see Appendix A). The Queensland Police Service (QPS) contains five main regions with multiple commands including specialist operations and strategy, policy, and performance groups (see Appendix B). Queensland has a history of police misconduct. Perhaps one of the most significant events was the Commission of Inquiry into Possible Illegal Activities and Associated Police Misconduct (Fitzgerald, 1989). The Inquiry found systemic and entrenched problems of police misconduct, mostly involving prostitution, gambling, and corruption (Lewis, et al., 2010). Despite changes to legislation and procedures since the Fitzgerald Inquiry, police misconduct continues in Queensland with a number of prominent cases. Throughout Queensland's more recent history ${ }^{2}$, incidences of police misconduct can be found that are consistent with many of the elements of established typologies (for example, Dean et al., 2010; Porter \& Warrender, 2009; Punch, 2000; Roebuck \& Barker, 1974), including excessive use force, inappropriate relationships with criminal informants, misuse of authority and failure of duty. Recently, the Crime and Corruption Commission (2020) reported that there were 5,442 complaints made about members of the Queensland Police for a one-year period (2016-2017). The three most frequently reported allegations were failure of duty,

\footnotetext{
${ }^{2}$ Including operations Capri, Nighthawk, and Tesco, the Violent Confrontations Review and Taskforces Bletchley and Flaxton, and the QPS Project Synergy
} 
conduct relating to the response to an incident, and assault/use of excessive force, with most of the allegations made about Senior Constables, Constables, and Sergeants. The consistent occurrence of police misconduct, and the breadth of the types of incidents that occur in Queensland, makes this a useful setting in which to examine such a topic.

\section{Sample and Data Collection}

The sample consists of 84 matters, or acts, contained within 49 cases of serious police misconduct. Cases were extracted from official archival sources. To obtain a valid data set, the sample consisted of only substantiated cases of police misconduct in Queensland, which included cases with a guilty finding or where the appeal against such a finding was not upheld. Investigations into police misconduct in Queensland can take two pathways; minor cases are examined internally within the Queensland Police Service (QPS), while matters of a more serious nature are investigated by the Crime and Corruption Commission (formerly known as the Crime and Misconduct Commission) (Crime and Misconduct Commission, 2010) (refer to Appendix $C$ for a detailed depiction of the process). Ultimately, the most serious $^{3}$ cases are heard at the Queensland Civil and Administrative Tribunal (QCAT) and are governed under the Crime and Misconduct Act 2001. QCAT hears and determines cases relating to police misconduct as well as reviewing appeals against decisions (QCAT, 2014). Cases of police misconduct are heard in the QCAT as 'Occupational Regulation Matters' and are available through an electronic database. Data were extracted from the entire online database available at the time of conducting this research, which contained transcripts of cases published between 18 May 2011 and 24 October 2017. Either party can appeal a case; this resulted in a number of cases regarding the same incident. In these circumstances, the information from the most recent case was used, and any previous cases for that incident were not included in the sample. The initial search yielded 106 court transcripts involving police officers (see Figure 2), of which 57 were excluded based on the existence of a more recent decision (such as appeal) (12 transcripts), cases not substantiated (8 transcripts), or irrelevance (such as applications for leave, non-publication orders, etc.) (37 transcripts). Consequently, $49^{4}$ serious police misconduct cases were included in the final sample for

\footnotetext{
${ }^{3}$ Serious cases include matters of official misconduct that if proven, provides reasonable grounds for dismissal or involves dishonest exercise of powers, breach of trust, or misuse of information (Crime and Misconduct Commission, 2010, p. 28-36).

4 This number of cases is consistent with the previous research on police misconduct. For example, Porter and Warrender (2009) examined 50 court cases of police misconduct while Dean and Gottschalk (2011) examined 60 court cases.
} 
analysis $^{5}$. These cases contained 84 separate matters (that is, separate behavioural subjects of consideration) of police misconduct that were dealt with.

\section{***INSERT FIGURE 2 HERE***}

\section{Strengths and Limitations of the Data Source}

The data were extracted from QCAT cases. Therefore, the information reported has been scrutinized through both the investigative process and the tribunal processes, thus making these documents a valuable and reliable source of information. It is important that testing the applicability of environmental theories be initially based on cases that have a high level of validity and authenticity in order to increase confidence in the findings. However, we acknowledge these data are limited in several ways. First, the data are limited to the information collected and presented by the original source. The purpose of a hearing differs somewhat to the purpose of the current research, and so not all information relevant to testing environment theories may be mentioned in the documents. For example, data could not be collected on background information or personal information of officers as this information is not reported in the original source. However, the purpose of the hearings is to evaluate the 'facts' presented and reach a reasonable decision over reliability and validity of that information, which is an important consideration for research data.

Second, while the data represents all recorded and substantiated cases of serious police misconduct in Queensland within the time frame, unsubstantiated or unrecorded incidences of police misconduct are not included in this sample, along with minor cases that are adjudicated internally within the police service. Thus, it is not an all-inclusive sample of police misconduct. Given the secretive nature of such acts, inclusivity will always be a problem for empirical research in this area. While most previous police misconduct research relies on complaints data to account for some of this dark figure, complaints data are not without issues. Complaints may be made falsely out of retaliation, or misunderstandings, amongst other reasons; conversely many people with a legitimate grievance do not make formal complaints (Grace \& Bucke 2009). Therefore, this information may also not reflect the true nature of police misconduct incidents. We suggest that an examination of

\footnotetext{
${ }^{5}$ All cases were unrelated with the exception of two cases that involved two different officers but related to the one event.
} 
substantiated cases provides a valuable initial test of the applicability of environmental theories to police misconduct, which can then be further tested on data from other sources.

\section{Data Coding}

A content analysis coding dictionary of features of the cases that are relevant to the elements of the crime triangle was created based on a combination of grounded theory and previously established police misconduct typologies. First, the initiation for the act was established adapted from Wortley's (2011) situational precipitators of crime. This included 'proactive' (a deviant act by an officer who proactively seeks out opportunities, for example an officer who knowingly accesses unauthorised information) and 'situational' (a deviant act by an officer as a response to the situation, for example an officer using inappropriate force after being 'provoked').

Fourteen categorical variables were identified based on Carmel-Gilfen's (2013) adaptation of Eck's (1994) crime triangle that represent the crime triangle's 'offender' and 'desire', 'place' and 'ability', and 'target' and 'opportunity' elements (see Appendix for all variable definitions and coding categories). As cases can include more than one matter of misconduct, all 84 matters of police misconduct were coded across all 14 crime triangle variables. The coding process can be subject to interpretations of the classifications allocated by coders. To produce a reliable data set, all cases were coded by two trained researchers. Discrepancies between the two raters were discussed, and the coding framework and definitions were refined until it was unambiguous.

\section{Analysis}

Each matter was the unit of analysis. First, frequency counts were explored for the categories of initiation (proactive versus situational) and each of the 14 crime triangle variables across the 84 matters. Second, because the study was particularly interested in the crime specific nature of the event, according to the situational precipitators that initiated the event, bivariate associations between the initiation (proactive versus situational) and the 14 crime triangle variables were explored using crosstabs. Data were analysed using Pearson Chi-Square, however, for $2 \times 2$ analysis, Yates Correction for Continuity was used and the standardised residuals were checked for significance. Of the 84 matters, 57 (67.86\%) involved officers proactively seeking out opportunities for misconduct while 25 (29.76\%) matters involved officers reacting to the situation. There were two matters in which the nature was unable to be established and, therefore, were not included in the second stage of analysis. 


\section{Results}

The results are organised by the elements of the crime triangle: offenders and desires, places and abilities, and targets and opportunities. Within these sections, first the frequencies for the crime triangle variables are presented for the whole sample of 84 matters, followed by the associations of these with the categories of initiation of the misconduct (see Table 2).

\section{***INSERT TABLE 2 HERE***}

\section{Offenders and Desires}

The gender and rank of the officers involved in the misconduct matters were explored in relation to the 'offender' aspect of the crime triangle. The 'desire' of the offenders was measured through the intention of the officers and the number of matters and events officers were involved in.

Gender and rank. Of the 84 matters, most deviant acts were conducted by males (77.38\%), which reflects the gender ratio within the QPS 6 . The ranks of the officers were more evenly distributed between low ranking officers (55.26\%) and higher ranking officers (44.74\%). The chi-square analysis indicated a significant association between officers' rank and the initiation for the misconduct $\chi^{2}(1)=4.036, p=.045$. In situationally initiated misconduct, officers were more often low ranking (73.08\%) compared to higher ranking officers (26.92\%), whereas proactively initiated incidents were more evenly proportioned between higher ranking $(54.00 \%)$ and low ranking (46.00\%) officers, however, the standardised residuals showed no significant differences to differentiate which group was contributing the most.

Intention. Typically, the intention of the officers was for personal gain (73.81\%) rather than for a noble cause $(26.19 \%)$. When the intention was for personal gain, these mostly occurred when officers proactively sought to commit misconduct (69.04\%). Indeed, there was a significant association between the intention and the initiation $\chi^{2}(1) 17.042$, $p<.001$. However, examination of the residuals found that this association was mainly driven by situational misconduct occurring more often than expected due to a noble cause ( standardised residual $=3.14$, corresponding to an alpha of .01). Alternatively, the residuals

\footnotetext{
${ }^{6}$ For example, in 2002 20\% of Queensland Police officers were female which rose to 26\% by 2016
} 
also revealed officers who proactively sought out misconduct were less often than expected doing so for a noble cause (standardised residual $=-2.10$, corresponding to an alpha of .05 ).

Matters and events. Across the whole sample, officers were mostly charged with multiple matters across multiple events $(46.43 \%)$ or committing a one-off act of misconduct $(40.48 \%)$ compared to officers who engaged in multiple acts of misconduct during a single event $(13.10 \%)$. The number of incidences the officer engaged in was significantly associated with the initiation $\chi^{2}(2)=11.209, p=.004$. Officers who proactively initiated misconduct were mostly involved in multiple matters across multiple events $(58.62 \%)$. Conversely, officers who engaged in situational misconduct were typically only involved in a single matter $(61.54 \%)$. However, the significant association was mainly driven by officers involved in multiple matters and multiple events due to situational initiations occurring less often than expected (standardised residual $=-2.04$, corresponding to an alpha of .05 ).

\section{Places and Abilities}

The place of the misconduct was explored in relation to the policing region where the matter took place and also the season of the year. The crime triangle aspect of 'ability' was examined through the site of the misconduct and the parties involved.

Region and season. Most matters took place during the seasons of Autumn (39.06\%) and Spring (26.56\%), followed by Summer and Winter (17.19\% each). There was no significant association between the seasons and the initiation. Additionally, there was no particular place (in terms of policing region) where police misconduct occurred more often.

Site. Most matters occurred at the police station or watch house $(51.81 \%)$ rather than in an entertainment precinct $(33.73 \%)$ or in a home $(14.46 \%)$. There was a significant association between the site of the transgression $\chi^{2}(2)=9.569, p=.008$ and the initiation. This association is mainly driven by situational misconduct occurring in a home more often than expected. However, the residual was only nearing the significance level of .05 $($ standardised residual $=1.78)$.

Participating parties. Most officers were committing acts of misconduct alone $(72.84 \%)$ with only $19.75 \%$ of officers committing the act with a fellow officer and $7.41 \%$ of officers committing the act with a member of the public. Interestingly, the chi-square analysis indicated that officers are less likely to engage in situational misconduct with another officer $\left(\chi^{2}(2)=6.192, p=.045\right.$, standardised residual $\left.=1.82\right)$. However, this should be treated with caution as one third of the cells ( 2 cells) had an expected count of less than five, violating the expected frequencies assumption. 


\section{Targets and Opportunities}

The crime triangle aspect of the 'target' of misconduct was explored through both the intended target as well as the resultant victim. The 'opportunity' for misconduct was explored through the means used to commit the misconduct, the nature of the interaction, the presence of bystanders and the duty status of the officers.

Target. In the majority of matters, the officers were targeting a person $(47.63 \%)$ or the intended target was the state/organisation (45.24\%) with only $7.14 \%$ of the officers targeting money/services/goods. The targeting of money/services/goods was always proactively initiated. However, officers who proactively initiated misconduct were almost always targeting the state/organisations (84.21\%) compared with officers who situationally initiated misconduct (15.78\%). Both proactive and situationally initiated misconduct equally involved targeting a person. Targeting a person occurred more often than expected in situational misconduct $\left(\chi^{2}(2)=13.568, p=.001\right.$, standardised residual $=2.17$, corresponding to an alpha of .05). However, this result should be treated cautiously due to 2 cells (33\%) having an expected count of less than five, violating the assumption of expected frequencies.

Resultant victim. The resultant victim categories were close to evenly split between the state/organization (55.95\%) and a person (45.05\%) for the sample. However, chi-square analysis revealed a statistically significant association between the resultant victim and initiation $\chi^{2}(1)=14.638, p<.001$. This association was mainly driven by the resultant victim being a person more often than expected in situational misconduct (standardised residual = 2.53, corresponding to an alpha of .05). Conversely, the resultant victim being the state/organisation occurred less often than expected in situationally initiated misconduct ( standardised residual $=-2.24$, corresponding to an alpha of .05 ).

Means. The means used to commit misconduct against intended target were generally evenly distributed across the sample cases, ranging from attitude and behaviour (34.52\%), information/forms/computer access $(29.76 \%)$, physical force $(21.43 \%)$, to gaining their target with the use of a vehicle (14.29\%) (such as officers who engaged in an unlawful vehicle pursuit). Chi-square analysis showed a significant association between the means and the initiation $\chi^{2}(3)=21.169, p<.001$. The residuals revealed that this association was mostly driven by situationally initiated matters of misconduct involving the use of physical force more often than expected (standardised residual $=3.15$, corresponding to an alpha of .01 ), while proactive misconduct matters were less likely to involve the use of physical force ( standardised residual $=-2.11$, corresponding to an alpha of .05 ). Furthermore, situationally 
initiated forms of misconduct were less likely to involve misuse of official information, forms or computer access (standardised residual $=-2.06$, corresponding to an alpha of .05).

Nature of interaction. Interactions were typically face-to-face (48.19\%). In $32.53 \%$ of the matters, the officer was using a remote method to reach their target (such as with the use of a telephone or computer). Some matters were facilitated with the use of a vehicle (19.28\%) such as drink driving and in matters of unlawful police pursuits. The chi-square analysis found no significant relationship between the nature of the interaction and initiation type.

Bystanders. Aside from participating parties in the misconduct (described above), the presence of bystanders, who were uninvolved in the misconduct, was explored. In most cases, a fellow police officer was present at the scene (44.9\%), however, there were some cases where the officer was alone (28.99\%) or a civilian was at the scene (26.09\%). Interestingly, where officers were proactively seeking out misconduct, a colleague was present in half of these matters $(51.11 \%)$. However, the chi-square analysis found no significant relationship between the presence of bystanders and initiation type.

Duty status. Mostly, the events were occurring while the officer was on duty (68.42\%) with only $31.58 \%$ of the matters while officers were off duty. While both proactive and situationally initiated matters mostly occurred whilst on duty, the disparity was greater in proactive misconduct, with three quarters of all proactive matters occurring whilst on duty (74.00\%). However, the chi-square analysis found no significant relationship between duty status and initiation.

\section{Discussion}

The present study explored the potential use of environmental theories to understand police misconduct. In doing so, it aimed to identify possible preventative techniques for police misconduct. To do this, the study utilised substantiated cases of police misconduct to extract elements of the crime triangle. Importantly, the study acknowledged the crime specific nature of police misconduct and examined these elements according to the situational precipitators that initiated the misconduct; that is, proactive and situational initiations. Indeed, the study revealed that the two types of initiation had differing relationships with the crime triangle elements. As such, more specific prevention techniques can be identified for each of the forms of misconduct and recommended to reduce or prevent police misconduct. The nature of proactive and situational misconduct is outlined below and discussed in terms of prevention techniques with particular reference to the second level of the crime triangle. 


\section{Proactively Initiated Police Misconduct}

The majority of the matters involved officers proactively seeking out opportunities (that is, officers were choosing to engage with misconduct rather than an unconscious reaction to the situation in which they found themselves). This presents an important potential for preventative interventions before the incident occurs. The frequencies of the crime triangle elements reveal that proactively initiated misconduct is most often engaged in for personal gain and less likely for a noble cause. Such matters also tend to be multiple for officers and across multiple events, suggesting a pattern of ongoing behaviour. The place in which proactively initiated misconduct occurs is most often in police stations or watch houses. Officers are most often acting alone to target the state or an organisation, ultimately resulting in the state/organisation being the resultant victim of the act. Most often, proactively initiated misconduct involves officers altering official forms or unlawfully accessing police computers to gain their target and are less likely to involve the use of physical force. Most often the officer is on duty at the time and there is a fellow police officer aware of the situation at the time or is present during the misconduct as a bystander. An example of proactively initiated misconduct within the sample cases is where an officer accessed QPS confidential data for personal reasons on multiple separate matters across multiple events in the officer's own station. While there were no other officers involved in the misconduct, there was another officer who suspected the behaviour and warned the officer. Misconduct such as inappropriately accessing sensitive and private information can lead to lack of trust in the police by the public, especially when this information is passed on to others (Crime and Corruption Commission, 2019).

This form of misconduct is somewhat similar to Punch's (2000) definition of 'police crime' described as 'police-initiated criminality' where 'crimes are committed by criminals in uniform' (p. 305). Likewise, Porter and Warrender's (2009) category of 'police crime' based on UK cases was characterised by lone officers committing acts for personal gain. However, those cases involved single incidents by predominantly junior officers and tended to encompass criminal behaviour, including assault and drink driving. In the present study, these proactive lone officers tend to be exhibiting a pattern of ongoing workplace misconduct.

\section{Prevention of Proactive Police Misconduct}

According to Clarke and Eck's (2003) crime triangle, in order to prevent crime from occurring, suitable handlers should be utilized to monitor potential offenders. Given that 
proactive misconduct mostly occurs at the police station via the use of computers, suitable monitoring of this place could be implemented, either electronically or through the roles of suitable personnel. For example, appointment of a data manager to monitor place would increase the effort needed to commit misconduct, by controlling access to facilities or systems. This would also help to increase the risk by reducing anonymity through requiring officers to formally request information from the data manager. Indeed, the Crime and Corruption Commission (2018) identified and acknowledged the problem of improper access to databases and recommended officers should provide their reasoning for accessing information and that warnings could be displayed to raise awareness (p. 3). Furthermore, implementing an independent auditor as a guardian to monitor the target may help to increase the risk and reduce proactive misconduct. Indeed, a strong and thorough oversight agency has been found successful in addressing police misconduct (Prenzler, 2011; Prenzler \& Ronken, 2001; Punch, 2000).

Given that these proactive cases seem to involve a pattern of ongoing behaviour, the role of workplace supervisors could also be utilized to make positive culture change, particularly against the proactive and 'personal gain' intention. Furthermore, this cultural change may also assist in encouraging fellow officers (who are aware of the situation or present at the time) to intervene as guardians. Indeed, research has shown that superiors who administer good controls can have a strong effect on the attitudes and behaviors of subordinates (Engel \& Worden, 2003; Lee \& Vaughn, 2010; Lim, et al., 2014). Embedding handlers at high ranks, who are ethical role models for officers, may aid in the prevention of police misconduct. Indeed, Tyler (2011) states that the "organizational culture of police departments is shaped by the values articulated by their leaders... Police officer behavior responds to the directives of the leadership, and tone from the top is crucial" (Tyler 2011, pp.261-262).

\section{Situationally Initiated Police Misconduct}

Conversely, situationally initiated misconduct was most often conducted by low ranking officers and more likely for a noble cause. Most often, these were a one-off event and less likely to involve multiple matters across multiple events. Mostly, situationally initiated misconduct occurred in entertainment precincts and the officer acted alone. Most often the officer targeted a person which, in turn, resulted in the victim more likely to be a person and less likely to be the state/organisation. These types of misconduct were most likely to involve the use of physical force and occur while the officer is on duty and in a face-to-face 
interaction, often with a civilian bystander witnessing the incident. An example case from the sample describes a male constable who was on duty and arresting a female suspect outside a busy Casino. To make the arrest, the officer used excessive force by pushing the suspect's head into the bonnet of the police vehicle. While the officer's partner was assisting in the arrest, the inappropriate use of force was only used by the assaulting officer.

Interestingly, Porter \& Warrender's (2009) study, noted previously, identified that one off incidents involving junior officers acting alone (in their UK sample) also involved the use of force, but tended towards criminal matters of assault and also tended to involve personal gain rather than a noble cause. However, it is noted that deviant behaviour for a noble cause in the current study was relatively rare. The present study, therefore, has identified some differences in the nature of cases that could be due to differences in the location, time period or the focus here on the type of initiation.

\section{Prevention of Situational Police Misconduct}

Agencies experiencing the elements of situational misconduct described above would benefit from the implementation of suitable handlers to create a positive cultural change against 'noble cause' intentions. Indeed, researchers have found that superiors who do not administer good controls can lead to higher frequencies of inappropriate uses of force (Fyfe, et al., 1997). However, in contrast to proactive misconduct, situational misconduct typically occurs in public, where formal supervision can be low but the likelihood of informal monitoring, in the form of civilian witnesses or bystanders, is high. Strengthening formal managers and surveillance (such as CCTV in entertainment districts) may increase the risk to this form of behaviour by officers. Additionally, ensuring an easy and accessible complaints management system for the public can help to extend guardianship, particularly when witnessed by fellow officers or civilian bystanders. In turn, this could increase the risk, with research finding success in disciplinary sentencing matrices that provide consistent responses to misconduct (Shane, 2012).

Situationally determined misconduct more likely involved the use of physical force than other forms of behaviour. Due to this violent nature, SCP techniques that reduce provocations by reducing frustrations and stress, reducing emotional arousal, neutralizing peer pressure, and discouraging imitation may be particularly useful. In one sample case, the Judge acknowledged the contributing factor of the stressful situations and the effects of the removal of this stress. Indeed, Bishop, Worall, and Piquero (2016) examined misconduct from a general strain perspective to suggest that police authorities should reduce strains to 
prevent misconduct from occurring, while Hassell \& Archbold (2010) found that more aggressive officers tend to generate greater numbers of complaints. Thus, strategies such as officer rotation (for shifts, duties, and geographical areas) may alleviate the build-up of stress associated with performing certain duties. For example, rotating an officer from a stressful road policing command to more positive community engagement practices (community contact command) in order to reduce the relentlessness of stressful situations. Research has shown that stressful situations can affect officers' cognitive, perceptual, and physiological ability to making decisions about force and the use of force (Hine, et al., 2018). In this sense, stress reduction programs have shown success in previous research (Patterson \& Chung, 2010). Programs may include training simulations that involve stress to neutralize the effects, such as use-of-force simulations or regular combat sports (Renden, 2015; Polis Solutions, 2018). Alternatively, meditation activities such as mindfulness have also been found to be beneficial in coping with stressful situations (Yeoman, 2017).

The misuse of force may also be combatted by removing excuses, which may prevent misconduct by setting rules that restrict discretionary decisions, alerting the conscience of officers to these rules, and by posting instructions as to these rules. Indeed, the excessive use of force within an agency can be normalized by excuses and justifications (Hunt, 1985). Zamperini, et al., (2017) analyzed media releases from the Italian Police unions to find a prevalence in excuses and justifications in the four controversial cases studied. Hence, removing these excuses and justifications may prevent the misconduct from occurring.

\section{Strengths and Limitations of the Study}

Police misconduct is a difficult topic to identify and measure, typically due to underreporting. The data used in this study represent a subset of cases that have been identified and substantiated through formal processes. As such, they represent cases at the more serious end of the spectrum that fit the remit of the QCAT and warranted disciplinary action. However, it could also be argued that the most serious incidents can produce the most devastating results, financially, physically, and emotionally. Focusing attention on serious matters may produce a dramatic reduction to the burden on society.

The data set gathered information from official data, making it a reliable approach. However, it is not without limitations, as noted earlier; it is constrained to the information contained in the transcripts, and the intent of the source. For example, the command that the officers were posted to at the time of the incident was unable to be identified from the data. Officers' command posting is important for future research to consider as, while the SCP 
approach itself is applicable to any command to identify misconduct problems and tailor prevention efforts, differences in duties (such as general duties, corporate services, investigative commands, etc.) are likely to provide different specific opportunities for police misconduct and, consequently, likely to involve different preventative approaches. Geographic information for the 'place' element of the crime triangle was limited, particularly in proportion to the high number of police districts and regions in Queensland. It is, therefore, perhaps unsurprising that few patterns were evident in this variable.

However, the study provides analysis that demonstrates the utility of the crime triangle framework in exploring the nature of cases, and provides illustrations of the application of SCP techniques. The next step is to examine the 'control' aspects of routine activity theory and the effects of implementing SCP techniques. An analysis of the current handlers, guardians, and managers needs to be conducted in conjunction with their effects on police misconduct prevention. Future studies should examine the effectiveness of the implementation of SCP techniques using pre-test and post-test measurements and/or, potentially, matched police districts as control/experimental groups.

Finally, SCP has its own critics. These criticisms focus mostly around displacement, ethical concerns, and the possible failure to address the root causes of issues. All of which can be debated. Studies have shown that displacement does not always occur or does not always occur to the full extent of the original crime (Weisburd, et al., 2006). Contrary to the theory of displacement, some studies have found a 'diffusion of benefits' (Weisburd et al., 2006). Critics of SCP raise concerns of social control (Davis 1990). However, not all forms of target hardening are invasive, some are hardly noticeable (such as vehicle identification numbers on automobile parts), and some contribute to reducing the fear of crime (such as street lighting). Finally, SCP has been criticized for failing to address the root causes of crime and does not always account for situational precipitators of crime (such as triggers caused by psychological trauma; particularly prevalent in policing (Cubitt \& Judges, 2018)) affecting the ability to make rational decisions, or for blaming the victims for not sufficiently guarding property. However, by blocking the opportunity for incidents to occur, deviant subcultures may fail to cultivate. This may be particularly relevant to policing, where police culture (or subcultures) has repeatedly been highlighted as contributing to misconduct (e.g. Paoline, 2003). 


\section{Conclusions}

This paper proposed a framework for identifying and preventing police misconduct based upon environment theories of crime. Such a framework improves on previous typologies that rely on simple description of the crime type to focus on specific elements and how these converge empirically in a sample of cases. The study explored these elements in relation to two initiations for police misconduct; proactive and situational. The findings suggest that these two types of police misconduct differ in nature and, as such, may require different prevention techniques. Overall, the findings suggest that an environmental approach to police misconduct may offer a feasible approach for a police department to not only understand the nature of police misconduct cases that they face, but also provide potential techniques to prevent misconduct from occurring.

\section{References}

Bishop, S. A., Worrall, J., \& Piquero, N. L. (2016). General strain and police misconduct: the role of organizational influence. Policing: An International Journal, 39(4), 635-651. doi:10.1108/PIJPSM-10-2015-0122

Carmel-Gilfilen, C. (2013). Bridging security and good design: Understanding perceptions of expert and novice shoplifters. Security Journal, 26(1), 80-105. doi:https://doi.org/10.1057/sj.2011.34

Clarke, R. V. (1990). Deterring obscene phone callers: Preliminary results of the New Jersey experience. Security Journal, 1(1), 143-148.

Clarke, R. V., 2010. Introduction. In R. Clarke (Eds), Situational crime prevention: Successful case studies (pp. 1-42). Boulder, Colorado: Rienner.

Cohen, L. E., \& Felson, M., 1979. Social change and crime rate trends: A routine activity approach. American Sociological Review, 44(4), 588-608. Retrieved from JSTOR database.

Cornish, D. B., \& Clarke, R. V. (2014). The reasoning criminal: Rational choice perspectives on offending. London: Transaction Publishers.

Crime and Corruption Commission. (2016). CCC corruption allegations. Brisbane: Crime and Corruption Commission.

Crime and Corruption Commission. (2020). Corruption allegations data dashboard. Retrieved from https://www.ccc.qld.gov.au/corruption/corruption-allegations-data-dashboard Crime and Corruption Commission. (2018). Prevention in focus: Improper access to public sector databases. Retrieved from 
https://www.ccc.qld.gov.au/sites/default/files/Docs/Publications/CCC/Prevention-inFocus-Improper-access-to-public-sector-databases-2018.pdf

Crime and Corruption Commission. (2019). Prevention in foucs: Improper access to public sector databases, no. 2. Retrieved from

https://www.ccc.qld.gov.au/sites/default/files/Docs/Publications/CCC/Prevention-inFocus-Improper-access-to-public-sector-databases-no2-2019.pdf

Crime and Misconduct Commission. (2010). Setting the standard: A review of current processes for the management of police discipline and misconduct matters. Brisbane: Crime and Corruption Commission.

Cubitt, T. I. C., \& Judges, J. H. (2018). Show cause analysis: A qualitative assessment of the factors influencing police misconduct from the perspective of officers who commit it. Policing: An International Journal, 41(6), 782-797. doi:10.1108/PIJPSM-06-20170079

Dean, G., Bell, P., \& Lauchs, M. (2010). Conceptual framework for managing knowledge of police deviance. Policing \& Society, 20(2), 204-222. doi:10.1080/10439461003668476

Dean, G., \& Gottschalk, P. (2011). Continuum of police crime: an empirical study of court cases. International Journal of Police Science \& Management, 13(1), 16-28. doi:10.1350/ijps.2011.13.1.222

Eck, J. E., 1994. Drug markets and drug places: A case-control study of the spatial structure of illicit drug dealing. Doctor of Philosophy, University of Maryland. United States. Retrieved March 03, 2012, from ProQuest Dissertations and Theses.

Ekblom, P. (1988). Preventing post office robberies in London: Effects and side effects. Journal of Security Administration, 11(2), 36-43.

Engel, R. S., \& Worden, R. E. (2003). Police officers' attitudes, behavior, and supervisory influences: An anlaysis of problem solving. Criminology, 41(1), 131-166. doi:10.1111/j.1745-9125.2003.tb00984.x

Fyfe, J. J., Greene, J. R., Walsh, W. F., Wilson, O. W., \& McLaren, R. C. (1997). Police administration: McGraw-Hill New York.

Grace, K. and Bucke, T. (2009) Public Annoyance and Complaints about the Police: Findings from the 2006/07 British Crime Survey, London: Independent Police Complaints Commission. 
Hassell, K. D. \& Archbold, C. A. (2010). Widening the scope on complaints of police misconduct. Policing: An International Journal, 33(3), 473-489. doi:10.1108/1369511011066863

Hauritz, M., Homel, R., McIlwain, G., Burrows, T., \& Townsley, M. (1998). Reducing violence in licensed venues through community safety action projects: The Queensland experience. Contemporary Drug Problems, 25(3), 511-551.

Hine, K. A., Porter, L. E., Westera, N. J., Alpert, G. P., \& Allen, A. (2018). Exploring Police Use of Force Decision-Making Processes and Impairments Using a Naturalistic Decision-Making Approach. Criminal Justice and Behavior, 45(11), 1782-1801. doi:10.1177/0093854818789726

Home Office. (2019). Police workforce, England and Wales, 30 September 2018: Statistical Bulletin. Retrieved from https://assets.publishing.service.gov.uk/government/uploads/system/uploads/attachme nt_data/file/772792/police-workforce-sep18-hosb0219.pdf

Hunt, J. (1985). Police Accounts of Normal Force. Urban Life, 13(4), 315-341. doi:10.1177/0098303985013004001

Kane, R. J. \& White, M. D. (2009). Bad cops: A study of career-ending misconduct among New York City police officers. Criminology \& Public Policy, 8(4), 797-769. Doi:10.1111/j.1745-9133.2009.00591.x

Kleinig, J. (1996). The ethics of policing. In. Cambridge: Cambridge University Press. Lee, H., \& Vaughn, M. S. (2010). Organizational factors that contribute to police deadly force liability. Journal of criminal justice, 38(2), 193-206. doi:10.1016/j.jcrimjus.2010.02.001

Lewis, C., Ransley, J., \& Homel, R. (2010). The Fitzgerald legacy. Sydney: Australian Academic Press.

Lim, H., Fridell, L., \& Lee, H. (2014). Multi-level analysis of police use of less-lethal force: The impact of incident characteristics, supervision, \& neighborhood context. Journal of Police Science, 14, 155-182.

Office of Police Integrity (Producer). (2012, July 30, 2012). The consequences of corruption. Retrieved from http://www.opi.vic.gov.au/index.php?t=4\&i=60\&m=69

Paoline, E. A. III (2003). Taking stock: Toward a richer understanding of police culture. Journal of Criminal Justice, 31, 199-214. 
Patterson, G. T., \& Chung, I. (2010). Stress management training and development programs for police officers and recruits. Oslo, Norway: The Campbell Collaboration.

Polis Solutions. (2018). T3 training: Tact, tactics, and trust. Retrieved from https://www.polis-solutions.net/t3

Porter, L. E., \& Warrender, C. (2009). A multivariate model of police deviance: examining the nature of corruption, crime and misconduct. Policing \& Society, 19(1), 79-99. doi:10.1080/10439460802457719

Punch, M. (2000). Police corruption and its prevention. European Journal on Criminology Policy and Research, 8(3), 301-324. doi:10.1023/A:10087703115

Prenzler, T. (2011). The evolution of police oversight in Australia. Policing and Society, 21(3), 284-303. doi:10.1080/10439463.2011.570866

Prenzler, T., \& Ronken, C. (2001). Models of police oversight: A critique. Policing and Society, 11(2), 151-180. doi:10.1080/10439463.2001.9964860

Punch, M. (2000). Police corruption and its prevention. European Journal on Criminal Policy and Research, 8(3), 301-324. doi:10.1023/A:1008777013115

Queensland Civil and Administrative Tribunal. (2014). Police officers and other prescribed persons. Retrieved from https:/www.qcat.qld.gov.au/matter-types/occupationalregulation-matters/prescribed-persons

Renden, P. (2015). Police performance under pressure: Arrest and self-defence skills. Amsterdam, The Netherlands: Department of Movement and Behavioral Sciences, Free University of Amsterdam.

Roebuck, J. B., \& Barker, T. (1974). A typology of police corruption. Social problems, 21(3), 423-437. doi:10.2307/799909

Sampson, R., Eck, J. E., \& Dunham, J. (2010). Super controllers and crime prevention: A routine activity explanation of crime prevention success and failure. Security Journal, $23,37-51$

Shane, J. M. (2012). Police employee disciplinary matrix: An emerging concept. Police Quarterly, 15(1), 62-91. doi:10.1177/1098611111433026

Sloan-Howitt, M., \& Kelling, G. (1990). Subway graffiti in New York City: Getting' up vs. meanin it and cleanin' it. Security Journal, 1(1), 131-136

Soo Son, I. \& Rome, D. M. (2004). The prevalence and visibility of police misconduct: A survey of citizens and police officers. Police Quarterly, 7(2), 179-204. doi:10.1177/1098611102250705 
Stinson, P. M., Liederbach, J., Lab, S. P., Brewer, S. L. (2016). Police integrity lost: A study of law enforcement officers arrested. U.S. Department of Justice. Retrieved from https://www.ncjrs.gov/pdffiles1/nij/grants/249850.pdf

Tyler, T. R. (2017). From harm reduction to community engagement: Redefining the goals of American policing in the twenty-first century. Northwestern University Law Review, 111(6), 1537-1564. Retrieved from HeinOnline.

Weisburd, D., Wycoff, L. A., Ready, J., Eck, J. E., Hinkle, J. C., \& Gajewski, F., 2006. Does crime just move around the corner: A controlled study of spatial displacement and diffusion of crime control benefits. Criminology, 44(3), 549-592. doi:10.1111/j.17459125.2006.00057.x

Wilkinson, P. (1986). Terrorism and the liberal state (2 ${ }^{\text {nd }}$ ed.). New York: New York University Press.

Wilson, J. Q. (1968). Varieties of police behaviour. Cambridge: Harvard University Press.

Worden, R. E., Harris, C., \& McLean, S. J. (2014). Risk assesment and risk management in policing. Policing: An International Journal, 37(2), 239-258. doi:10.1108/PIJPSM12-2012-0088

Wortley, R. (2011). Situational precipitators of crime. In R. Wortley \& L. Mazerolle (Eds.), Environmental criminology and crime analysis. New York: Routledge

Wortley, R., Blumstein, A., \& Farrington, D. (2002). Situational prison control: Crime prevention in correctional institutions. Melbourne: Cambridge University Press.

Yeoman, B. (2017, June 14). Mindful policing: The future of force. Mindful: Healthy mind, healthy life. Available from https://www.mindful.org

Zamperini, A., Siracusa, V., \& Menegatto, M. (2017). Accountability and police violence: A research on accounts to cope with excessive use of force in Italy. Journal of Police and Criminal Psychology, 32(2), 172-183. doi:10.1007/s11896-016-9208-7 


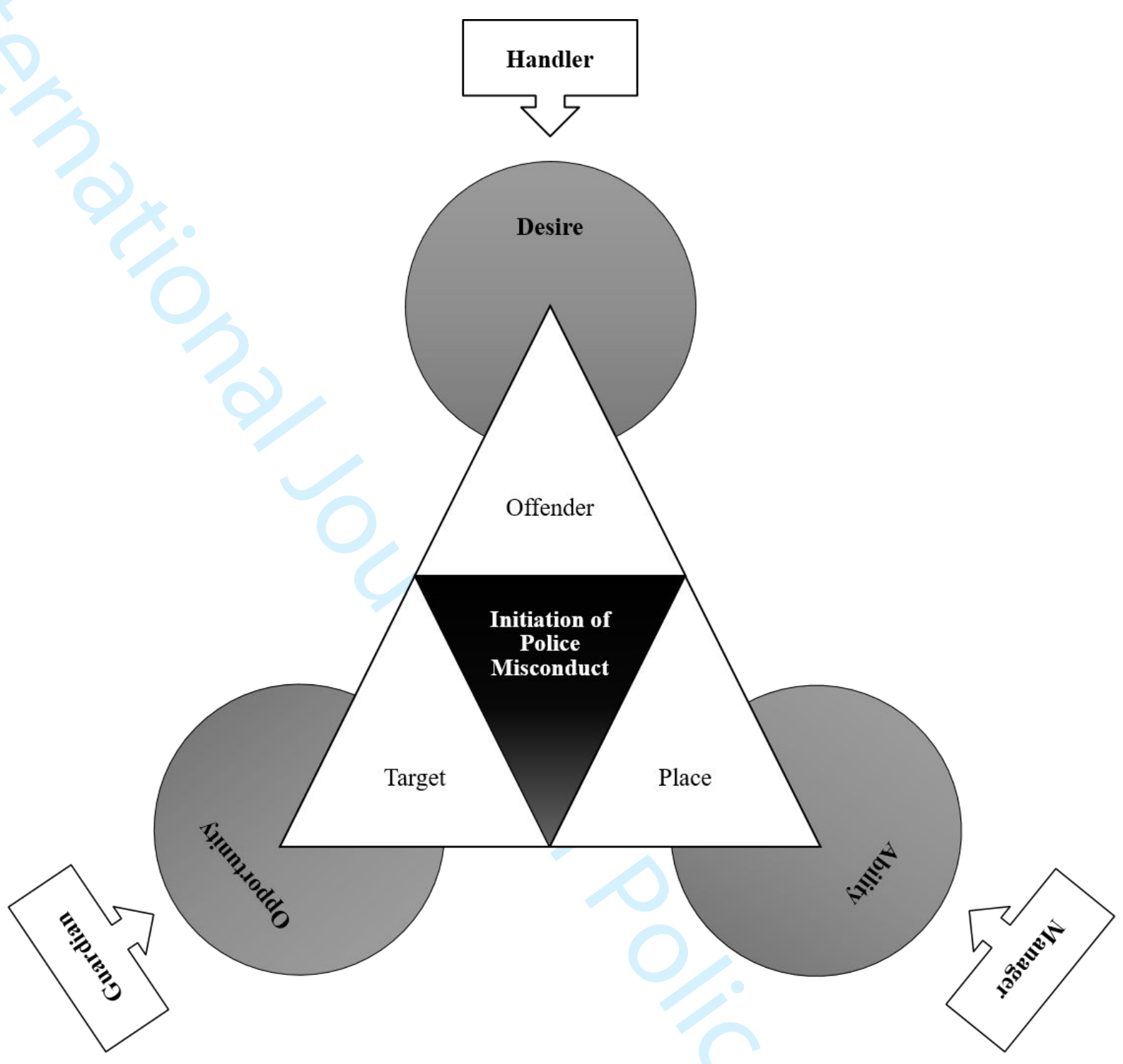

Figure 1. Police misconduct triangle adapted from Eck (1994), Carmel-Gilfilen (2013), and Wortley (2011) 


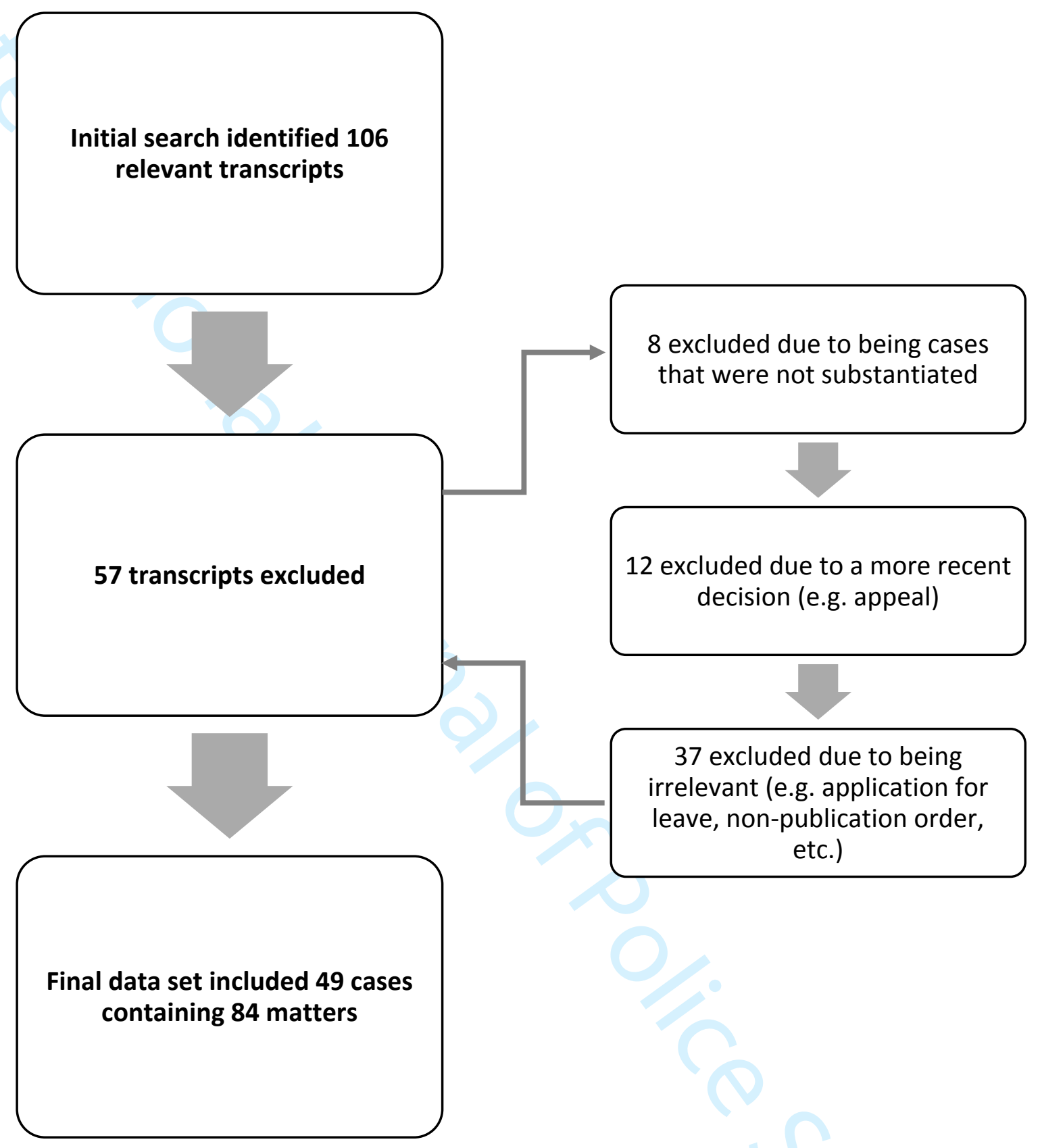

Figure 2. Data collection process 
Table 1 . The 25 techniques of situational crime prevention.

\begin{tabular}{|c|c|c|c|c|}
\hline $\begin{array}{c}\text { Increase the } \\
\text { Effort }\end{array}$ & $\begin{array}{c}\text { Increase the } \\
\text { Risk }\end{array}$ & $\begin{array}{l}\text { Reduce the } \\
\text { Rewards }\end{array}$ & $\begin{array}{c}\text { Reduce } \\
\text { Provocations }\end{array}$ & $\begin{array}{l}\text { Remove } \\
\text { Excuses }\end{array}$ \\
\hline $\begin{array}{c}1 \\
\text { Target } \\
\text { hardening }\end{array}$ & $\begin{array}{c}6 \\
\text { Extend } \\
\text { guardianship }\end{array}$ & $\begin{array}{c}11 \\
\text { Conceal targets }\end{array}$ & $\begin{array}{c}16 \\
\text { Reduce } \\
\text { frustrations and } \\
\text { stress }\end{array}$ & $\begin{array}{c}21 \\
\text { Set rules }\end{array}$ \\
\hline $\begin{array}{c}2 \\
\text { Control access } \\
\text { to facilities }\end{array}$ & $\begin{array}{c}7 \\
\text { Assist natural } \\
\text { surveillance }\end{array}$ & $\begin{array}{c}12 \\
\text { Remove targets }\end{array}$ & $\begin{array}{c}17 \\
\text { Avoid disputes }\end{array}$ & $\begin{array}{c}22 \\
\text { Post } \\
\text { instructions }\end{array}$ \\
\hline $\begin{array}{c}3 \\
\text { Screen exits }\end{array}$ & $\begin{array}{c}8 \\
\text { Reduce } \\
\text { anonymity }\end{array}$ & $\begin{array}{l}13 \\
\text { Identify } \\
\text { property }\end{array}$ & $\begin{array}{c}18 \\
\text { Reduce } \\
\text { emotional } \\
\text { arousal }\end{array}$ & $\begin{array}{c}23 \\
\text { Alert } \\
\text { conscience }\end{array}$ \\
\hline $\begin{array}{c}4 \\
\text { Deflect } \\
\text { offenders }\end{array}$ & $\begin{array}{c}9 \\
\text { Utilize place } \\
\text { managers }\end{array}$ & $\begin{array}{c}14 \\
\text { Disrupt markets }\end{array}$ & $\begin{array}{c}19 \\
\text { Neutralize peer } \\
\text { pressure }\end{array}$ & $\begin{array}{c}24 \\
\text { Assist } \\
\text { compliance }\end{array}$ \\
\hline $\begin{array}{c}5 \\
\text { Control tools or } \\
\text { weapons }\end{array}$ & $\begin{array}{c}10 \\
\text { Strengthen } \\
\text { formal } \\
\text { surveillance }\end{array}$ & $\begin{array}{c}15 \\
\text { Deny benefits }\end{array}$ & $\begin{array}{c}20 \\
\text { Discourage } \\
\text { imitation }\end{array}$ & $\begin{array}{l}25 \\
\text { Control drugs } \\
\text { and alcohol }\end{array}$ \\
\hline
\end{tabular}

Source: (Cornish \& Clarke 2003, p. 90) 
Table 2. Chi-square analysis of the nature of police misconduct.

\begin{tabular}{|c|c|c|c|c|c|c|c|c|c|c|c|}
\hline & & & \multicolumn{2}{|c|}{ Proactive } & \multicolumn{2}{|c|}{ Situational } & \multirow[b]{2}{*}{$\mathrm{N}$} & \multirow[b]{2}{*}{$\mathrm{x} 2$} & \multirow[b]{2}{*}{$\mathrm{df}$} & \multirow[b]{2}{*}{$\mathrm{p}$ Value } \\
\hline & & Variable & Category & $\mathrm{n}$ & $\%$ & $\mathrm{n}$ & $\%$ & & & & \\
\hline \multirow{9}{*}{ ț } & \multirow{4}{*}{ 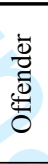 } & \multirow{2}{*}{ Gender } & Male & 43 & 74.14 & 22 & 85.62 & 65 & 0.607 & 1 & 0.436 \\
\hline & & & Female & 15 & 25.86 & 4 & 15.38 & 19 & & & \\
\hline & & \multirow{2}{*}{ Rank } & Lower Ranking Officer & 23 & 46.00 & 19 & 73.08 & 42 & 4.036 & 1 & 0.045 \\
\hline & & & Higher Ranking Officer & 27 & 54.00 & 7 & 26.92 & 34 & & & \\
\hline & \multirow{5}{*}{ 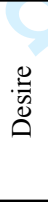 } & \multirow{2}{*}{ Intention } & Noble Cause & 7 & $\downarrow \mathbf{1 2 . 0 7}$ & 15 & $\uparrow 57.69$ & 22 & 17.042 & 1 & 0.000 \\
\hline & & & Personal Gain & 51 & 87.93 & 11 & 42.31 & 62 & & & \\
\hline & & \multirow{3}{*}{$\begin{array}{l}\text { Matters and } \\
\text { Events }\end{array}$} & Single Matter, Single Event & 18 & 31.03 & 16 & 61.54 & 34 & 11.209 & 2 & 0.004 \\
\hline & & & Multiple Matters, Single Event & 6 & 10.34 & 5 & 19.23 & 11 & & & \\
\hline & & & Multiple Matters, Multiple Events & 34 & 58.62 & 5 & $\downarrow 19.23$ & 39 & & & \\
\hline \multirow{15}{*}{$\frac{\mathscr{\Xi}}{\Delta}$} & \multirow{9}{*}{$\frac{\mathscr{J}}{2}$} & \multirow{4}{*}{ Season } & Summer & 6 & 14.63 & 5 & 21.74 & 11 & 0.795 & 3 & 0.851 \\
\hline & & & Autumn & 16 & 39.02 & 9 & 39.13 & 25 & & & \\
\hline & & & Winter & 8 & 19.51 & 3 & 13.04 & 11 & & & \\
\hline & & & Spring & 11 & 26.83 & 6 & 26.09 & 17 & & & \\
\hline & & \multirow{5}{*}{$\begin{array}{l}\text { Police } \\
\text { Region }\end{array}$} & \multirow{5}{*}{$\begin{array}{l}\text { Northern } \\
\text { Southern } \\
\text { Central } \\
\text { South Eastern } \\
\text { Brisbane }\end{array}$} & 9 & 19.57 & 2 & 8.00 & 11 & 8.171 & 4 & 0.086 \\
\hline & & & & 2 & 4.35 & 6 & 24.00 & 8 & & & \\
\hline & & & & 9 & 19.57 & 4 & 16.00 & 13 & & & \\
\hline & & & & 8 & 17.39 & 2 & 8.00 & 10 & & & \\
\hline & & & & 18 & 39.13 & 11 & 44.00 & 29 & & & \\
\hline & \multirow{6}{*}{ 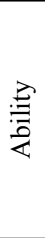 } & \multirow{3}{*}{ Site } & \multirow{3}{*}{$\begin{array}{l}\text { Entertainment Precinct/Street } \\
\text { Home } \\
\text { Police Station/Watch House }\end{array}$} & 17 & 29.31 & 11 & 44.00 & 28 & 9.569 & 2 & 0.008 \\
\hline & & & & 5 & 8.62 & 7 & 28.00 & 12 & & & \\
\hline & & & & 36 & 62.07 & 7 & 28.00 & 43 & & & \\
\hline & & & Alone & 36 & 65.45 & 23 & 88.46 & 59 & 6.192 & 2 & 0.045 \\
\hline & & $\begin{array}{l}\text { Participatıng } \\
\text { Parties }\end{array}$ & Internal & 15 & 27.27 & 1 & 3.85 & 16 & & & \\
\hline & & & External & 4 & 7.27 & 2 & 7.69 & 6 & & & \\
\hline & & & Money/Services/Goods & 6 & 10.34 & 0 & 0 & 6 & 13.568 & 2 & 0.001 \\
\hline & & $\begin{array}{l}\text { Intended } \\
\text { Target }\end{array}$ & Person & 20 & 34.48 & 20 & $\uparrow 76.90$ & 40 & & & \\
\hline & $\frac{5}{\pi}$ & & State/Organisation & 32 & 55.17 & 6 & 23.08 & 38 & & & \\
\hline & & Resultant & Person & 17 & 29.31 & 20 & $\uparrow 76.92$ & 37 & 14.638 & 1 & 0.000 \\
\hline & & Victim & State/Organization & 41 & 70.69 & 6 & $\downarrow 23.08$ & 47 & & & \\
\hline & & & Attitude and Behaviour & 22 & 37.93 & 7 & 26.92 & 29 & 21.169 & 3 & 0.000 \\
\hline & & Means & Information/Forms/Computer Access & 23 & 39.66 & 2 & $\downarrow 7.69$ & 25 & & & \\
\hline & & Means & Physical Force & 5 & $\downarrow 8.62$ & 13 & $\uparrow \mathbf{5 0 . 0 0}$ & 18 & & & \\
\hline$\stackrel{500}{\pi}$ & & & Vehicle & 8 & 13.79 & 4 & 15.38 & 12 & & & \\
\hline & $\stackrel{?}{=}$ & & Face-to-Face & 23 & 40.35 & 17 & 65.38 & 40 & 4.678 & 2 & 0.096 \\
\hline & 㤩 & Interaction & Vehicular & 12 & 21.05 & 4 & 15.38 & 16 & & & \\
\hline & 莒 & & Remote & 22 & 38.60 & 5 & 19.23 & 27 & & & \\
\hline & $0^{2}$ & & Alone & 14 & 31.11 & 6 & 25.00 & 20 & 4.727 & 2 & 0.094 \\
\hline & & Bystander & Police Officer & 23 & 51.11 & 8 & 33.33 & 31 & & & \\
\hline & & & Civilian & 8 & 17.78 & 10 & 41.67 & 18 & & & \\
\hline & & Duty Status & On Duty & 37 & 74.00 & 15 & 57.69 & 52 & 1.418 & 1 & 0.234 \\
\hline & & & Off Duty & 13 & 26.00 & 11 & 42.31 & 24 & & & \\
\hline
\end{tabular}


Appendix A

Average number of sworn officers for each policing jurisdiction in Australia (2002-2019) according to each jurisdiction's annual report

\begin{tabular}{lrrr}
\hline \multicolumn{1}{c}{ Policing Jurisdiction } & $\begin{array}{c}\text { Average Number } \\
\text { of Sworn Officers }\end{array}$ & $\begin{array}{c}\text { Average } \\
\text { Population }\end{array}$ & Size km $^{2}$ \\
\hline New South Wales & 15,743 & $7,193,655$ & 800,628 \\
Victoria & 13,457 & $5,955,875$ & 227,010 \\
Queensland & 13,184 & $4,390,952$ & $1,723,936$ \\
Western Australia & 5,879 & 229,062 & $2,526,786$ \\
South Australia & 4,554 & $1,626,315$ & 978,810 \\
Tasmania & 1,224 & 512,951 & 64,519 \\
Northern Territory & 1,224 & 226,073 & $1,335,742$ \\
Australian Federal Police & 3,036 & & \\
\hline
\end{tabular}




\section{Appendix B}

Organisational structure according to the Queensland Police annual reports 2013-2017
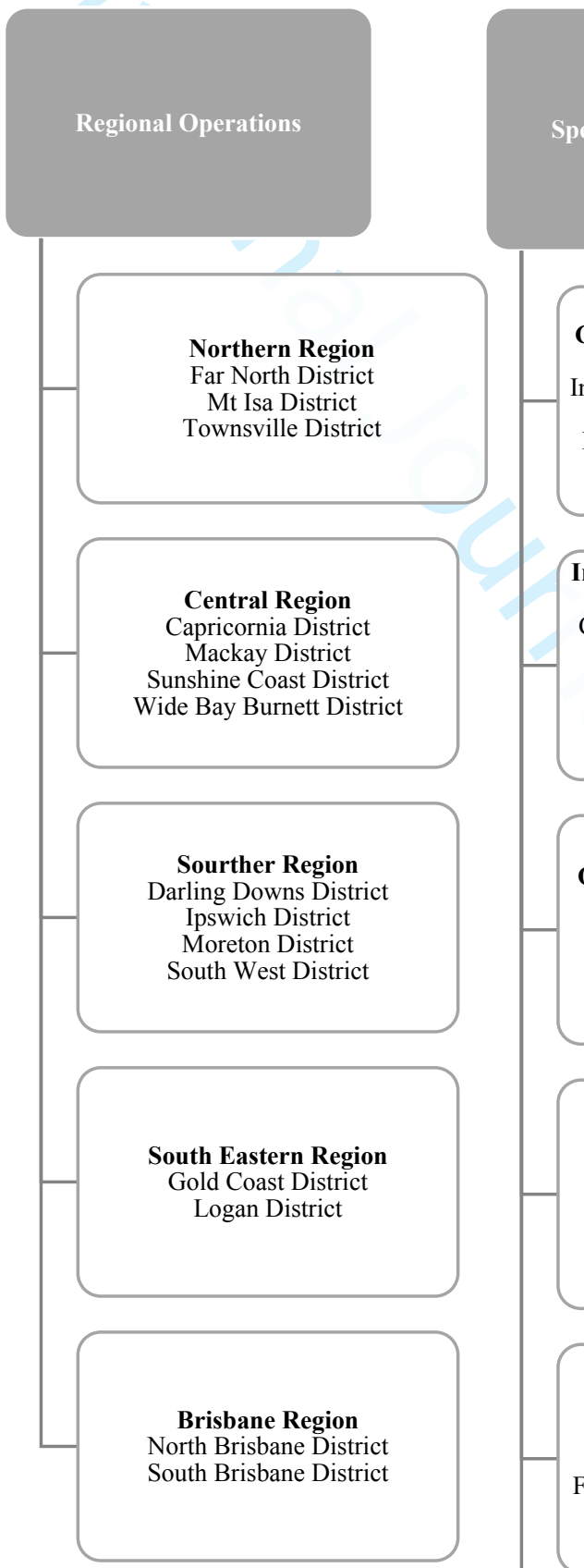

Specialist Operations

Community Contact Command Communications Group Information Management Services Group

Media and Public Affairs Group Policelink and Programs Group

Intelligence, Counter-Terrorism and Major Events Command Covert and Specialist Operations Group

Security and Counter-Terrorism Group

State Intelligence Group Strategic Intelligence Group

Operations Support Command

Forensic Services Group

Protective Services Group

Specialist Response Group

Specialist Services Group
Road Policing Command

Road Policing Command Operations

Road Policing Coimmand Engagement

Road Safety Camera Office
State Crime Command

Child Safety and Sexual Crime Group

Drugand Serious Crime Group Financial and Cyber Crime Group Homicide Group

Organised Crime Gangs Group

Commonwealth Games Group G20 Group
Strategy, Policy and

Performance

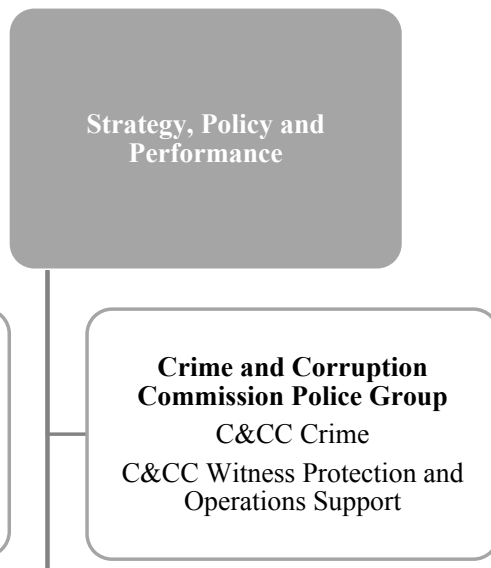

Ethical Standards Commands

Integrity and Performance

Internal Investigations

\section{Legal Division}

Information and Discipline

Support Services

Legal Services

Prosecution Services

Organisational Capability Command

Business Improvement Governance

Policy and Performance Engagement Legislation

Planning and Performance Strategic Policy

People Capability Command Operational Policing and Leadership

Recruit and Constable Trainng

Safety and Recruiting

Training Strategy 


\section{Appendix C}

QPS discipline system according to Crime and Misconduct Commission, 2010, p. 26

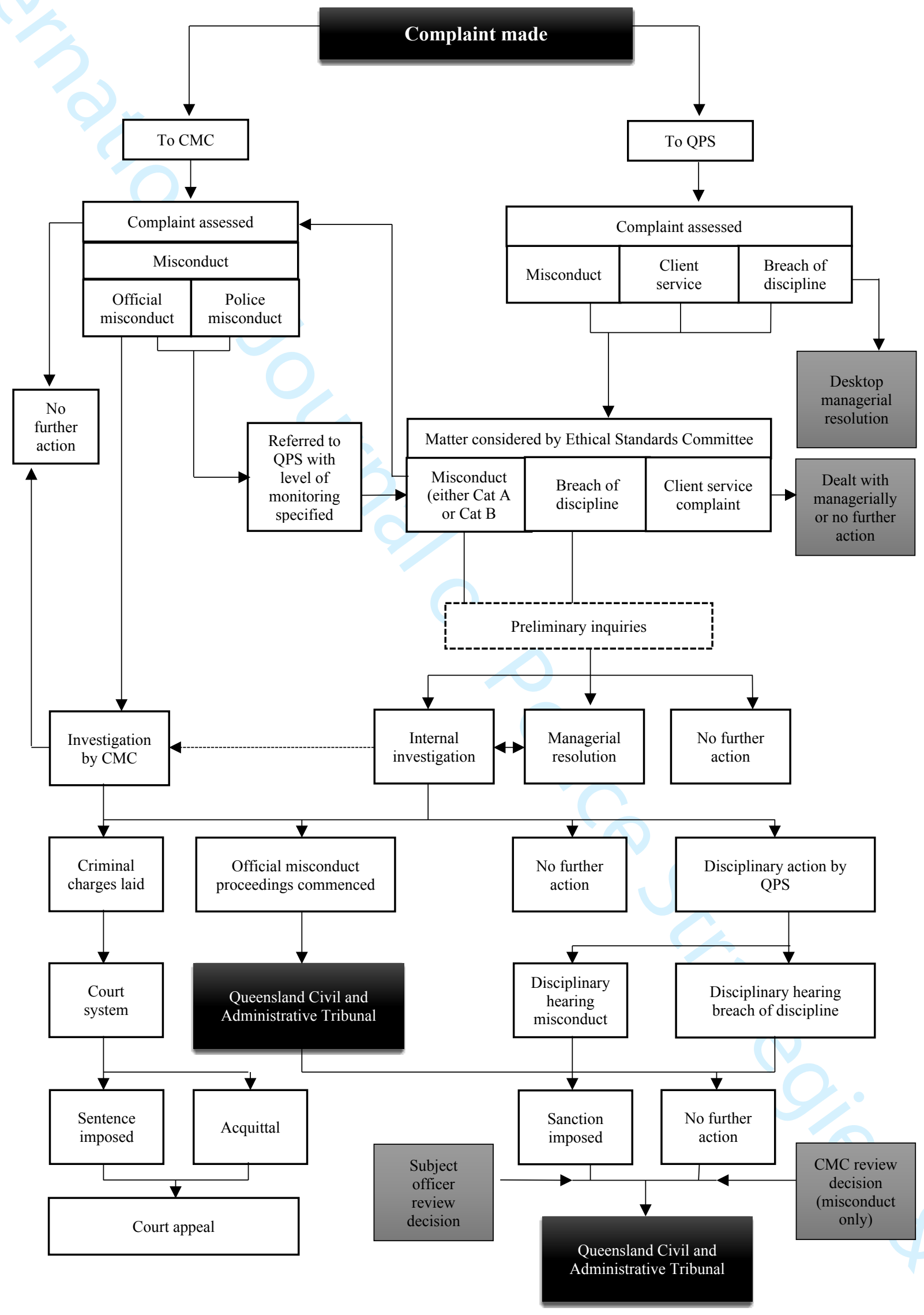




\section{Appendix D}

Crime triangle elements exploring the current nature of police misconduct.

\begin{tabular}{|c|c|c|c|c|}
\hline \multicolumn{2}{|c|}{ Element } & Variable & Description & Code \\
\hline \multicolumn{2}{|c|}{$\begin{array}{l}\text { Situational } \\
\text { Precipitator }\end{array}$} & Initiation & $\begin{array}{l}\text { The situational precipitators that initiated the misconduct. } \\
\text { Coded as proactive (the misconduct is initiated by the } \\
\text { officer, seeking out the opportunity) or situational (the } \\
\text { misconduct occurred as a response to the situation). }\end{array}$ & $\begin{array}{l}\text { Proactive } \\
\text { Situational }\end{array}$ \\
\hline \multirow{4}{*}{ 离 } & \multirow[b]{2}{*}{ 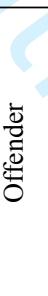 } & Gender & The gender of the officer. & $\begin{array}{l}\text { Male } \\
\text { Female }\end{array}$ \\
\hline & & Rank & $\begin{array}{l}\text { The officer's rank at the time of incident. Higher ranking } \\
\text { officers included officers ranked at Sergeant or above as } \\
\text { these levels are most likely to involve a mentoring and } \\
\text { supervisory role to lower ranking officers. However, it } \\
\text { should also be noted that Constables and Senior } \\
\text { Constables also play a mentoring role for less experienced } \\
\text { officers such as Probationary Constables. }\end{array}$ & $\begin{array}{l}\text { Lower Ranking Officer } \\
\text { Higher Ranking Officer }\end{array}$ \\
\hline & \multirow{2}{*}{$\begin{array}{l}\stackrel{\mathscr{S}}{\mathscr{0}} \\
\stackrel{\mathscr{D}}{0}\end{array}$} & Intention & $\begin{array}{l}\text { The intention for the act. Coded as noble cause (the } \\
\text { misconduct is carried out for the greater good such as } \\
\text { engaging in unauthorised police pursuit to apprehend the } \\
\text { suspect) or personal gain (direct gain to the officer such as } \\
\text { lying for promotions or accessing confidential information } \\
\text { about personal relations) }\end{array}$ & $\begin{array}{l}\text { Noble Cause } \\
\text { Personal Gain }\end{array}$ \\
\hline & & $\begin{array}{l}\text { Matters and } \\
\text { Events }\end{array}$ & $\begin{array}{l}\text { Whether the officer's charges involved a single matter } \\
\text { (the charge) or a number of different matters and whether } \\
\text { these matters surrounded a single event (contemporaneous } \\
\text { incident) or multiple events occurring at different times or } \\
\text { places. }\end{array}$ & $\begin{array}{l}\text { Single Matter, Single Event } \\
\text { Multiple Matters, Single Event } \\
\text { Multiple Matters, Multiple Events }\end{array}$ \\
\hline \multirow{4}{*}{$\frac{\mathscr{E}}{2}$} & \multirow[b]{2}{*}{$\frac{\mathscr{\pi}}{\pi}$} & Season & $\begin{array}{l}\text { The season (southern hemisphere) in which the } \\
\text { misconduct occurred. }\end{array}$ & $\begin{array}{l}\text { Summer } \\
\text { Autumn } \\
\text { Winter } \\
\text { Spring }\end{array}$ \\
\hline & & Police Region & $\begin{array}{l}\text { The police region in which the offence was committed. } \\
\text { Queensland is divided into eight policing regions. } \\
\text { However, within the data set, the police misconduct took } \\
\text { place in only five regions. }\end{array}$ & $\begin{array}{l}\text { Northern } \\
\text { Southern } \\
\text { Central } \\
\text { South Eastern } \\
\text { Brisbane }\end{array}$ \\
\hline & \multirow{2}{*}{$\stackrel{?}{:}$} & Site & The site where the transgression occurred. & $\begin{array}{l}\text { Entertainment Precinct/Street } \\
\text { Home } \\
\text { Police Station/Watch House }\end{array}$ \\
\hline & & $\begin{array}{l}\text { Participating } \\
\text { Parties }\end{array}$ & $\begin{array}{l}\text { Persons involved in carrying out the misconduct coded as } \\
\text { either internally (with another officer), externally (with a } \\
\text { civilian), or alone. }\end{array}$ & $\begin{array}{l}\text { Alone } \\
\text { Internal } \\
\text { External }\end{array}$ \\
\hline \multirow{6}{*}{ 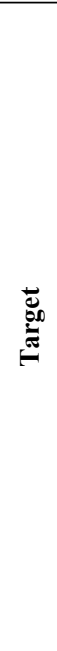 } & \multirow{2}{*}{ 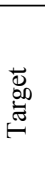 } & Intended Target & $\begin{array}{l}\text { The intended target is the object of the action for example } \\
\text { the money an officer is trying to misappropriate. }\end{array}$ & $\begin{array}{l}\text { Money/Services/Goods } \\
\text { Person } \\
\text { State/Organisation }\end{array}$ \\
\hline & & $\begin{array}{l}\text { Resultant } \\
\text { Victim }\end{array}$ & $\begin{array}{l}\text { The resultant victim is the subject of the misconduct who } \\
\text { is directly affected by the misconduct for example the } \\
\text { owner of the money }\end{array}$ & $\begin{array}{l}\text { Person } \\
\text { State/Organization }\end{array}$ \\
\hline & \multirow{4}{*}{$\begin{array}{l}\text { 离 } \\
\text { 咅 } \\
\text { 高 }\end{array}$} & Means & The means the offender used to commit the misconduct. & $\begin{array}{l}\text { Attitude and Behaviour } \\
\text { Information/Forms/Computer Access } \\
\text { Physical Force } \\
\text { Vehicle }\end{array}$ \\
\hline & & Interaction & $\begin{array}{l}\text { The nature of the interaction in terms of how the } \\
\text { misconduct occurred. }\end{array}$ & $\begin{array}{l}\text { Face-to-Face } \\
\text { Vehicular } \\
\text { Remote } \\
\text { Other }\end{array}$ \\
\hline & & Bystander & $\begin{array}{l}\text { Parties present during the event who are not directly } \\
\text { involved in carrying out the misconduct for example } \\
\text { witnesses. That is, independent parties who are not the } \\
\text { officer, target/victim, nor participating party. }\end{array}$ & $\begin{array}{l}\text { Alone } \\
\text { Police Officer } \\
\text { Civilian }\end{array}$ \\
\hline & & Duty Status & Duty status at the time of the event (on-duty or off-duty). & $\begin{array}{l}\text { On Duty } \\
\text { Off Duty }\end{array}$ \\
\hline
\end{tabular}

